\title{
Role of annexin A family in tumorigenesis and chemoresistance of gastric cancer
}

\section{Minireview}

Rong-Rong ZHAO ${ }^{1,2,3}$, Xiao-Rong $\mathrm{MAO}^{3}$, Xiao-Feng WANG ${ }^{1,2,3}$, Ya ZHENG ${ }^{1,2}$, Yu-Ping WANG ${ }^{1,2, *}$, Yong-Ning ZHOU ${ }^{1,2, *}$

${ }^{1}$ Department of Gastroenterology, The First Hospital of Lanzhou University, Lanzhou, Gansu, China; ${ }^{2}$ Key Laboratory for Gastrointestinal Diseases of Gansu Province, The First Hospital of Lanzhou University, Lanzhou, Gansu, China; ${ }^{3}$ Department of Infectious Diseases, The First Hospital of Lanzhou University, Lanzhou, Gansu, China

*Correspondence: zhouyn@lzu.edu.cn; wangyuping@lzu.edu.cn

Received June 29, 2021 / Accepted September 24, 2021

\begin{abstract}
Gastric cancer (GC) is one of the most common cancer types and the fourth leading cause of cancer-related mortality among all malignant tumors worldwide. Due to insidious onset and lack of reliable early diagnostic markers, most GC patients are at an advanced stage at the time of diagnosis. Annexin is an evolutionally-conserved $\mathrm{Ca}^{2+}$-dependent phospholipid-binding protein superfamily, including five members (A, B, C, D, and E). Annexins in the cells of vertebrates comprised the annexin A family, consisting of 12 members in humans. The biological functions of annexin $\mathrm{A}$ are $\mathrm{Ca}^{2+}$-signal transduction, vesicle transport, cell proliferation, cell division, cell apoptosis, signal transduction, anti-inflammatory, proangiogenesis, and anticoagulation, most of which overlap with the basic characteristics of tumors. Accumulating evidence indicated that members of the annexin A family are correlated with tumorigenesis and chemoresistance and can be used as potential tumor prognostic factors and targets for biological therapy. Thus, the current review focused on the role and relative mechanisms of the annexin A family in GC.
\end{abstract}

Key words: annexin A family, gastric cancer, therapeutic target, chemoresistance

According to the latest GLOBOCAN statistics from the World Health Organization, GC ranks fifth in incidence and fourth in mortality globally, with approximately 1,080,000 new cases and 769,000 deaths in 2020 [2]. Due to the insidious onset and lack of reliable early diagnostic markers, only $10 \%$ of patients are diagnosed at the early stage [3]. Most GC patients are already at an advanced stage at the time of diagnosis and have missed the opportunity of radical surgery, rendering the 5-year survival rate was only $10-30 \%$ $[4,5]$. Despite recent advances in molecular targeting and immunotherapy therapies directed against GC, such as human epidermal growth factor receptor 2 (HER2) [6, 7], immune checkpoints, and other related pathways and targets $[8,9]$, most of them are in the stage of clinical experiments. Thus, in-depth investigation in the pathogenesis of GC and exploration of potential therapeutic targets at the molecular level are crucial for screening out new molecular biomarkers on the early diagnosis and evaluation of prognosis of GC to optimize treatment regimens.

Annexin is an evolutionally-conserved $\mathrm{Ca}^{2+}$-dependent phospholipid-binding protein superfamily widely distributed in eukaryotes cells. It is also known as a calcium-phospholipid binding protein and consists of five members: A, B, C, $D$, and E [10]. Annexins in the vertebrate cells are defined as annexin A family that comprises 12 members in humans, Annexin A 1-11 and A 13 [11, 12]. The abnormal expression of annexin A family members is closely related to the occurrence and development of many diseases, such as autoimmune diseases, acute and chronic inflammation [13-15]. Accumulating studies have shown that the abnormal expression levels of annexin A family members are strongly correlated to tumor formation, thereby serving as potential tumor prognostic factors and effective targets for biological therapy [16-18]. In this review, we summarized the proposed roles of 
the annexin A family in GC tumorigenesis, chemoresistance, and as potential molecular markers for the early diagnosis and as therapeutic targets.

\section{Structure and function of annexin A family}

Each member of the annexin A family has been verified to possess two structural domains: C-terminal and N-terminal [19]. The C-terminal domain, also known as the core region, is a highly helical and tightly folded protein center consisting of four repeat units, each containing 70 conserved amino acids that exist as five tight helices, forming the annexin domain. This domain binds to calcium-ion phospholipid and fibrin protein $[20,21]$. It also contains biofilm-binding sites and proteolysis sites that promote the interaction between the annexin and cell membrane, which in turn plays a crucial role in cytoskeleton reassembly and modulation [10]. The $\mathrm{N}$-terminal domain, also termed the tail domain, is a variable region consisting of 10 or 20 amino acid residues. The structure includes the post-translational modification sites, the proteolysis site, and binding sites with other proteins; these belong to the regulatory domains of the molecule involved in the bioactivity of multitude proteins [22].

Hitherto, the members of the annexin A family are implicated in several physiological functions in humans, such as vesicle transport, cell proliferation, cell division, cell apoptosis, cell invasion and metastasis, signal transduction, anti-inflammation, proangiogenesis, and anticoagulation [10, 22-24]. The hallmarks of cancer harbor six basic biological capabilities, including sustaining proliferative signaling, evading growth suppressors, resisting cell death, enabling replicative immortality, inducing angiogenesis, and activating invasion and metastasis [25]. As seen from the above accounts, the partial biological functions of the annexin A family overlap with the basic characteristics of tumors. Therefore, a large number of studies have focused on annexin A family members and tumors in recent years. ANXA3 and ANXA9 can promote migration and invasion while suppressing the apoptosis of colorectal cancer cells, they may be potential biomarkers for predicting poor prognosis in colorectal cancer patients [26-28]. ANXA1 can facilitate the growth and migration of breast cancer by modulating the function of Treg cells and tumor-associated macrophages in the tumor microenvironment [29, 30]. Herein, we primarily reviewed the advances of the clinical significance and the molecular mechanism of the annexin A family in GC (Table 1, Table 2).

ANXA1 in GC. ANXA1 is the first member discovered of the annexin superfamily, which primarily localizes in the cytoplasmic membrane and is connected to the cytoskeleton. It is a major inflammatory regulatory protein that exerts an anti-inflammatory effect via glucocorticoids [31] and inhibits the synthesis and release of inflammatory cytokines, such as cyclooxidase 2 (COX-2) and nitric oxide synthase (NOX) [32]. In recent years, ANXA1 has been reported to be involved in a variety of tumor biological processes, including proliferation, apoptosis, migration, and angiogenesis [33-36].

As an anti-inflammatory mediator, ANXA1 repairs the damaged gastric mucosa in mice with stomach ulcers [37]. Compared to normal gastric mucosa, ANXA1 protein was significantly increased in human intestinal metaplasia and gastric ulcer [38], chronic gastritis, and gastric polyps, and a positive correlation was established between ANXA1 and COX-2 in chronic gastritis [39]. Cristina et al. [40] reported that the expression of ANXA1 at the mRNA and protein level was overexpressed in both gastritis and GC. The above results suggested that the continuous inflammatory process of gastric mucosa might lead to an uncontrolled expression of ANXA1, which might play a significant role in precancerous lesions of GC. However, the effect of ANXA1 in advanced GC is yet controversial. Zhang et al. [41] and Wang et al. [42] screened out the differentially expressed proteins in GC and adjacent tissues by proteomics and further verified by immunohistochemistry. The findings suggested that ANXA1 was upregulated in GC tissue compared to normal adjacent tissues, and high ANXA1 expression was associated with high tumor node metastasis (TNM) classification [41]. ANXA1 staining was also related to serosal invasion, peritoneal metastasis [43], vascular metastasis, Union for International Cancer Control (UICC) staging [44], and poor overall survival in GC patients [43, 44]. Furthermore, ANXA1 was found to promote the migration and invasion of GC cells by gain- and lost-of-function strategies [42]. The underlying mechanism may be mediated through the activation of formyl peptide receptor (FPRs)/ extracellular signal-regulated kinase (ERK)/integrin beta1-binding protein 1 (ITGB1BP1) signaling pathway [43]. Unlike the aforementioned reports, some researchers constructed tissue microarray blocks containing primary GC, lymph node metastasis, and adjacent normal mucosa specimens obtained from 1072 Chinese patients; a complete loss of ANXA1 expression was observed in 691/1072 (64\%) primary tumors and $146 / 169$ (86\%) nodal metastasis by immunohistochemistry [45]. The loss of ANXA1 expression was significantly relevant to the advanced TNM stage and poor histological differentiation [45]. In addition, Gao et al. [46] detected the expression of ANXA1 mRNA and protein in GC and adjacent tissues using quantitative real-time PCR (qRT-PCR), immunohistochemistry, and western blotting assay, and all the methods indicated that ANXA1 was downregulated in GC. Moreover, the forced ANXA1 expression in GC cells inhibits cell proliferation and migration [46]. Notably, a study revealed that ANXA1 was expressed in both the cytoplasm and nucleus of gastric adenocarcinoma (GA) tissues, while the positive nuclear staining is correlated with serosal invasion, peritoneal dissemination, and high TNM stage. These phenomena suggested that the subcellular localization of ANXA1 in GC is related to the prognosis [47]. Although the functional research results 
Table 1. Clinical significance of annexin A family in gastric cancer.

\begin{tabular}{|c|c|c|c|c|}
\hline $\begin{array}{l}\text { Member } \\
\text { name }\end{array}$ & $\begin{array}{l}\text { Molecular mass } \\
(\mathrm{Da})\end{array}$ & Expression & Clinicopathological features & Ref \\
\hline ANXA1 & 38714 & Up-regulation & & {$[40]$} \\
\hline ANXA1 & 38714 & Up-regulation & $\begin{array}{l}\text { Deeper invasive depth ( } \mathrm{T} \text { stage) } \\
\text { More lymph node metastasis (N stage) } \\
\text { More distant metastasis (M stage) } \\
\text { High tumor-lymph node metastasis stage }\end{array}$ & {$[41]$} \\
\hline ANXA1 & 38714 & Up-regulation & $\begin{array}{l}\text { More cancer invasion } \\
\text { More lymph node metastasis Advanced UICC stage } \\
\text { Poor OS }\end{array}$ & {$[44]$} \\
\hline ANXA1 & 38714 & Up-regulation & $\begin{array}{l}\text { More peritoneal metastasis } \\
\text { More serosal invasion } \\
\text { Poor OS }\end{array}$ & [43] \\
\hline ANXA1 & 38714 & Down-regulation & $\begin{array}{l}\text { Advanced T stage } \\
\text { Lymph node metastasis } \\
\text { Advanced disease stage } \\
\text { Poor histological differentiation } \\
\text { Poor survival rates }\end{array}$ & {$[45]$} \\
\hline ANXA2 & 38604 & Up-regulation & $\begin{array}{l}\text { Larger tumor size } \\
\text { Poor histological differentiation } \\
\text { High TNM staging } \\
\text { More lymph node metastasis }\end{array}$ & [59] \\
\hline ANXA2 & 38604 & Up-regulation & $\begin{array}{l}\text { Location of tumor } \\
\text { Larger size of tumor } \\
\text { Poor differentiation } \\
\text { Histological type } \\
\text { Deeper depth of invasion } \\
\text { vessel invasion } \\
\text { More lymph node metastasis } \\
\text { More distant metastasis } \\
\text { High TNM stage } \\
\text { Poor cumulative five-year survival rates }\end{array}$ & {$[51]$} \\
\hline ANXA3 & 36375 & Up-regulation & Inferior differentiation degree & [82] \\
\hline ANXA7 & 52739 & Up-regulation & $\begin{array}{l}\text { High pathological stage } \\
\text { More lymphatic metastasis } \\
\text { Poor clinical outcomes }\end{array}$ & [97] \\
\hline ANXA8 & 36881 & Up-regulation & $\begin{array}{l}\text { High TNM stage } \\
\text { Poor differentiation grades } \\
\text { Poor OS } \\
\text { Poor DFS }\end{array}$ & [104] \\
\hline ANXA10 & 37278 & Down-regulation & $\begin{array}{l}\text { High TNM stage } \\
\text { Advanced gastric carcinoma } \\
\text { More lymph node metastasis } \\
\text { Poor survival }\end{array}$ & [110] \\
\hline ANXA10 & 37278 & $\begin{array}{l}\text { Down-regulation in early } \\
\text { GC }\end{array}$ & $\begin{array}{l}\text { Poor OS } \\
\text { Poor PFS }\end{array}$ & [113] \\
\hline ANXA11 & 54390 & Up-regulation & $\begin{array}{l}\text { Larger tumor size } \\
\text { Deeper tumor infiltration } \\
\text { More local lymph node metastasis } \\
\text { High TNM staging } \\
\text { More vascular invasion }\end{array}$ & [121] \\
\hline
\end{tabular}

Abbreviations: OS-Overall survival; DFS-Disease-free survival; PFS-progression-free survival rate; TNM-Tumor node metastasis; UICC-Union for International Cancer Control

of ANXA1 in advanced GC are not uniform, the study on the targeted therapy of ANXA1 has been reported in GC. Recently, Feng et al. [48] demonstrated that ANXA1 binds to and stabilizes erythropoietin-producing hepatocellular receptor tyrosine kinase subtype A2 (EphA2) in GC cells. Strikingly, the ANXA1-EphA2 interaction is disrupted by the two ANXA1-derived peptides that inhibit the growth of
GC cells by targeting EphA2 degradation, proposing a novel idea for the targeted therapeutic strategy of GC.

In summary, previous studies about ANXA1 in GC have provided the following interpretations: the high expression of ANXA1 in precancerous lesions of GC was uniform and its high expression may be associated with tumorigenesis, whereas the large difference in ANXA1 was observed in 
progressive GC. The possible interpretations for the differences were subcellular localization and nuclear translocation of ANXA1 in GC, tissue specimens from different ethnic groups and disease stages. In addition, a new molecular classification of GC based on The Cancer Genome Atlas (TCGA), defined the major genomic subtypes of GC: Epstein-Barr virus (EBV) infected tumors, microsatellite unstable (MSI) tumors, genomically stable tumors, and chromosomally unstable tumors [49]. Therefore, we speculated that different molecular subtypes are also involved in the differential expression of ANXA1.
ANXA2 in GC. ANXA2 is the most extensively investigated member of the annexin A family. It plays a major role in vascular tissue remodeling, proliferation, apoptosis, migration, adhesion, and other biological functions [50], and it is also involved in maintaining the physiological function of embryonic and mesenchymal stem cells [51, 52]. Several studies have demonstrated that the abnormal expression of ANXA2 in numerous tumors is associated with biological behaviors, including cell cycle regulation, neoangiogenesis, growth, and invasion $[16,53,54]$. These findings could render ANXA2 as the promising biomarker

Table 2. Mechanism of annexin A family in gastric cancer.

\begin{tabular}{|c|c|c|c|c|}
\hline $\begin{array}{l}\text { Member } \\
\text { name }\end{array}$ & Dysregulation & Biological function & Specific mechanism & Ref \\
\hline ANXA1 & Up-regulation & Promotes migration and invasion & Activates FPRs/ERK/ITGB1BP1 Pathway & {$[43]$} \\
\hline ANXA1 & Up-regulation & Promotes migration and invasion & & {$[42]$} \\
\hline ANXA1 & Down-regulation & Inhibits proliferation and migration & Abrogates COX-2 expression & {$[46]$} \\
\hline ANXA2 & Up-regulation & $\begin{array}{l}\text { Promotes proliferation, invasion and } \\
\text { migration } \\
\text { Inhibits apoptosis rates }\end{array}$ & & {$[58]$} \\
\hline ANXA2 & Up-regulation & Promotes invasion and metastasis & Up-regulates MMP-2, MMP-9 & {$[59]$} \\
\hline ANXA3 & Up-regulation & $\begin{array}{l}\text { Promotes proliferation, invasion and } \\
\text { metastasis }\end{array}$ & $\begin{array}{l}\text { Down-regulates p21, p27, TIMP-1, TIMP-2 } \\
\text { Up-regulates PCNA, cyclin D1, MMP-1, MMP-2 }\end{array}$ & {$[67]$} \\
\hline ANXA4 & Up-regulation & Promotes proliferation & $\begin{array}{l}\text { Activation of RHAMM, AKT and CDK1 } \\
\text { Suppression of p } 21\end{array}$ & {$[81]$} \\
\hline ANXA4 & Up-regulation & Promotes tumor angiogenesis & Induces IL-8 secretion & {$[79]$} \\
\hline ANXA4 & Up-regulation & Promotes the invasion and EMT & miR-203-ANXA4 axis & {$[82]$} \\
\hline ANXA6 & Down-regulation & Inhibits proliferation & $\begin{array}{l}\text { Methylation of the typical CpG island (CGI) in the promoter region } \\
\text { of ANXA6 } \\
\text { Inhibition of Ras/MAPK signaling }\end{array}$ & {$[88]$} \\
\hline ANXA6 & Down-regulation & Inhibits proliferation & Repressed by EZH2-mediated H3K27me3 & {$[90]$} \\
\hline ANXA7 & Up-regulation & $\begin{array}{l}\text { Promotes proliferation, migration and } \\
\text { invasion }\end{array}$ & $\begin{array}{l}\text { Down-regulates p16, p21, p27 } \\
\text { Up-regulates PCNA, Cyclin A, Cyclin D1, Cyclin E1, MMP-2, MMP- } \\
\text { 9, ICAM-1 }\end{array}$ & {$[99]$} \\
\hline ANXA7 & Up-regulation & Inhibits cell apoptosis & $\begin{array}{l}\text { Up-regulates Bcl-2 } \\
\text { Down-regulates Bax, Caspase-3, Caspase- } 9\end{array}$ & {$[100]$} \\
\hline ANXA10 & Down-regulation & $\begin{array}{l}\text { Inhibits proliferation } \\
\text { Increases apoptosis }\end{array}$ & & {$[114]$} \\
\hline ANXA11 & Up-regulation & $\begin{array}{l}\text { Promotes proliferation, migration and } \\
\text { invasion }\end{array}$ & Activates AKT/GSK-3b pathway & {$[121]$} \\
\hline
\end{tabular}

Abbreviations: FPR-ERK-ITGB1BP1-Formyl peptide receptor- extracellular signal-regulated kinase- integrin beta-1-binding protein 1; RHAMM-Hyaluronan mediated motility receptor; H3K27me3-Trimethylation of histone H3 lysine 27

Table 3. The role of annexin A family in chemotherapy resistance of GC.

\begin{tabular}{|c|c|c|c|c|}
\hline Member name & Chemotherapeutics & $\begin{array}{l}\text { Effects on } \\
\text { chemosensitivity }\end{array}$ & Specific mechanism & Ref \\
\hline ANXA2 & Doxorubicin, 5-Fu, Cisplatin & Decrease & $\begin{array}{l}\text { Up-regulated P-gp, MRP1 and Bcl-2 } \\
\text { Down-regulated Bax } \\
\text { Regulated p38-Mark and Akt signaling pathways }\end{array}$ & {$[124]$} \\
\hline ANXA2 & Cisplatin or vincristine & Decrease & miR-101-ANXA2-P-pg axis & {$[129]$} \\
\hline ANXA2 & 5-Fu, Cisplatin, Mitomycin C & Decrease & ZNF139-ANXA2/fascin-PDXK axis & {$[130]$} \\
\hline ANXA5 & 5-Fu, Cisplatin, Paclitaxel & Decrease & Up-regulated MRP1 & {$[136]$} \\
\hline ANXA5 & Docetaxel+Cisplatin+S-1 (DCS) & Decrease & & {$[137]$} \\
\hline ANXA6 in CAF-EV of GC & Cisplatin & Decrease & $\begin{array}{l}\text { Activated FAK-YAP signaling pathway by } \\
\text { stabilizing } \beta 1 \text { integrin }\end{array}$ & [138] \\
\hline
\end{tabular}


for tumor diagnosis and prognosis and a candidate target for tumor therapy [55-57]. Unlike ANXA1, the expression level of ANXA2 in GC and paracarcinoma tissue was consistent [58-60]. High ANXA2 expression in GC was significantly correlated with tumor size, histological differentiation, TNM stage, lymph node metastasis, depth of invasion, distant metastasis, and high S100A6 expression; S100A6 combined with ANXA2 proteins is a valuable marker predicting GC progression and prognosis $[59,60]$. Furthermore, ANXA2 silencing weakens the proliferation, invasion, and migration in GC cells [58], and promotes the invasion and metastasis of GC by increasing the secretion of matrix metalloproteinases (MMPs) [60]. ANXA2 exists as a part of the heterotetrameric complex with S100A10, AHNAK, and actin proteins involved in the transport of ion channels and membrane receptors to the plasma membrane and from the plasma membrane to the intracellular region $[12,61]$. A recent study reported that $\$ 100 \mathrm{~A} 10$ activated the Akt/mTOR signaling pathway by interacting with ANXA2 to accelerate tumor glycolysis, resulting in the malignant progression of GC [62]. In conclusion, the high expression of ANXA2 is correlated to the proliferation, invasion, metastasis, and prognosis of GC, thereby necessitating the verification of ANXA2 in the prognosis, diagnosis, and target validity of GC.

ANXA3 in GC. ANXA3 is also known as a lipid cortical protein or placental anticoagulant protein 3 [63]. Previous studies have shown that ANXA3 has a role in multiple aspects of cell differentiation, cell migration, immune regulation of bone formation, and calcification [22, 64]. In recent years, ANXA3 has been successively reported to plays different roles in various tumors $[24,26,65,66]$. It might be a tumor-suppressor in thyroid carcinoma [65] and prostate cancer [66] or a tumor-promoter in breast cancer [24] and colorectal cancer [26], depending on the type of tumor cells and tissues. The expression of ANXA3 was significantly upregulated in GC tissues and negatively correlated with the differentiation degree. Downregulating the expression of ANXA3 in GC cells significantly inhibited proliferation, migration, and invasion. The underlying mechanism may be associated with the altered expression level of p21, p27, tissue inhibitor of metalloproteinase-1 (TIMP-1), TIMP-2, proliferating Cell Nuclear Antigen (PCNA), cyclin D1, MMP-1, and MMP-2 proteins, involved in classical proliferation, invasion, and cell cycle-related proteins in tumors [67]. Ochratoxin A (OTA) is one of the most abundant food-contaminating mycotoxins. A recent study showed that OTA exposure induces malignant transformation of human gastric mucosal epithelial cells (GES-1) in vitro, while inhibition of ANXA3 by siRNA effectively prevents the proliferation, migration, and invasion abilities of GES-1 cells [68]. Therefore, ANXA3 may be involved in the mycotoxin-induced malignant transformation of normal gastric mucosa cells, and the specific mechanism requires further exploration and investigation.
ANXA4 in GC. ANXA4 is speculated to be involved in exocytosis and regulation of epithelial Cl- secretion [20]. Recent studies showed that ANXA4 is upregulated in a variety of malignant tumors and tightly associated with tumor differentiation, clinical stage, and clinical prognosis of colorectal cancer [69], ovarian clear cell carcinoma [70, 71], kidney cancer [72], and prostate cancer [73]. Moreover, it could mediate tumor cell apoptosis, proliferation, invasion, and metastasis and participate in resistance to chemotherapeutic drugs, playing a significant role in tumor progression [74-78]. Li et al. [79] reported that ANXA4 was overexpressed in both Helicobacter pylori (Hp)-infected GC tissues and SCM-1 cells. $\mathrm{Ca}^{2+}$ is induced by $\mathrm{Hp}$ and interacts with ANXA4 $\mathrm{Ca}^{2+}$ binding site to attenuate the calmodulin-activated chloride conductance, creating a new environment that benefits the malignant existence of $\mathrm{Hp}$ [79]. Meanwhile, due to the translocation to the plasma membrane, the structure and localization of ANXA4 were altered, thereby enhancing the cell plasma membrane repair response induced by $\mathrm{Hp}$ and increasing the risk of GC [80]. Moreover, the overexpression of ANXA4 in SCM-1 cells with Hp infection may subsequently induce interleukin-8 (IL-8), which could further cause tumor angiogenesis, thereby deeming ANXA4 as a potential novel molecular marker for GC with $\mathrm{Hp}$ infection [79]. Another study revealed that ANXA4 promotes gastric tumor cell proliferation; the underlying mechanism may be associated with the activation of the hyaluronic acid-mediated motor receptor (RHAMM), protein kinase $\mathrm{B}(\mathrm{PKT})$, cyclin-dependent kinase 1 (CDK1), and inhibition of p21 [81]. Importantly, miRNA negatively regulates the target genes in GC. microRNA-203 also inhibited the invasion and epithelial-mesenchymal transition (EMT) of GC cells by targeting ANXA4, and the reactivation of the micro-203/ANXA4 axis may represent a novel strategy for suppressing the metastasis of GC [82]. Overall, ANXA4 promotes GC malignant progression by triggering the inflammatory cascades of $\mathrm{Hp}$ infection and oncogenic signaling.

ANXA6 in GC. ANXA6 is the largest molecular weight protein in the annexin A family [83]. It structurally varies from the other members of the annexin A family, consisting of eight rather than four repeats [84]. Previous studies have shown that ANXA6 plays opposite roles in different tumor tissues and cells. In melanoma [85], squamous carcinoma [86], ANXA6 shows a tumor-suppressive effect while exerting the role of an oncogene in cervical cancer [87]. Wang et al. [88] showed that the mRNA level of ANXA6 was downregulated in GC cell lines and tissues compared to gastric mucosa epithelial cells and normal adjacent tissues. Interestingly, the methylation of the typical CpG island (CGI) in the promoter region of the ANXA6 gene in GC cells is the main reason for its downregulation, and Yin Yang 1 (YY1) may initiate or maintain ANXA6 promoter methylation in GC cells [88]. Conversely, the ectopic ANXA6 expression inhibited the growth of cells and the activity of Ras/MAPK (mitogen- 
activated protein kinase) signaling, exerting an antitumor role in GC [88]. A histone methyltransferase enhancer of zeste homolog 2 (EZH2) is frequently overexpressed in GC, and its high expression is closely related to tumor size, depth of invasion, vessel invasion, lymph node metastasis, and clinical stages [89]. Qi et al. [90] utilized genome-wide transcriptional profiling analysis to identify ANXA6 as the target gene of EZH2 in GC cells. The study also found that ANXA6 mRNA was downregulated in five GC cell lines compared to the normal gastric mucosa epithelial cell, whereas the overexpression of ANXA6 inhibits the proliferation ability of GC cells [90]. The underlying mechanism may be connected to the targeting of EZH2 to ANXA6 by catalyzing the trimethylation of histone $\mathrm{H} 3$ lysine 27 (H3K27Me3) [90]. In conclusion, low ANXA6 expression of GC is implicated in the epigenetic modifications, especially DNA methylation, and may be a novel therapeutic target for inhibiting GC.

ANXA7 in GC. ANXA7 is an important member of the annexin A family. Several studies demonstrated that the aberrant expression of ANXA7 plays a major role in the occurrence and development of a variety of tumors, such as hepatocellular carcinoma [91], multiple myeloma [92], glioma [93], prostate cancer [94], and breast cancer [95]. In 2008, a study reported a striking correlation between ANXA7 expression and the differentiated degree of GC, and the ANXA7 expression was higher in intestinal-type than in diffuse-type tumor. The loss of ANXA7 expression was significantly related to distant metastasis [96]. Another study found that high ANXA7 expression was associated with poor differentiation in GC patients, and it may be a predictor for lymphatic metastasis of GC [97]. The primary GC specimens with lymph node metastasis (LNM) showed 25\% higher ANXA7 expression relative to the primary GC tissue without LNM [98]. The silencing of endogenous ANXA7 suppressed the proliferation, migration, and invasion abilities of the BGC823 cells via cell cycle regulators (including p16, p21, p27, cyclin A, cyclin D1, and cyclin E1) and the expression of MMP-1, MMP-2, and intercellular cell adhesion molecule-1 (ICAM-1) [99]. Moreover, inhibiting the expression of ANXA7 in BGC823 cells induced a more than five-fold increase in apoptosis, significantly decreased the expression of anti-apoptotic protein $\mathrm{Bcl}-2$, and increased the expression of pro-apoptotic proteins, Bax, Caspase-3, and Caspase-9 [100]. Overall, the high expression of ANXA7 was useful for the determination of LNM and the pathological types of GC and served as an indicator to predict the poor prognosis of patients with GC. Regarding the biological function, ANXA7 might promote the growth and metastasis of GC by affecting the proliferation, apoptosis, and invasion and regulating the cell cycle.

ANXA8 in GC. ANXA8 has been explored in only a few studies. It regulates late endosome organization and function, which would affect the lysosomal targeting of EGFR and signal output, while the EGFR/Ras/MAPK pathway is one of the most important signaling cascades involved in the development of various tumors [101, 102]. ANXA8 is also reported to be involved in maintaining immune homeostasis [103]. To date, only a single study has assessed the expression of ANXA8 in GC. Also, elevated expression of ANXA8 was detected in GC tumor tissues [104]. The overexpression of ANXA8 was significantly correlated with TNM stages and tumor differentiation grades. The increased expression of ANXA8 was strongly associated with overall survival (OS) and disease-free survival (DFS) in GC patients. Moreover, ANXA8 is an independent prognostic factor of OS and DFS of GC patients [104]. ANXA8 could be used as an oncogene and a potential prognostic biomarker for GC; however, the specific molecular mechanism needs to be delineated further.

ANXA10 in GC. ANXA10 is a newly identified member of the annexin A family, and hence, its physiological function in humans remains unclear. Only a few studies have been reported about ANXA10 and its varied role in different types of tumors [105]. Furthermore, ANXA10 is mapped on chromosome $4 \mathrm{q} 33$, while the variation of chromosome $4 \mathrm{q}$ was a prominent feature of hepatocellular carcinoma (HCC), which is lowly expressed in hepatoma tissues and acted as a tumor suppressor in HCC [106-108]. Contrarily, ANXA10 plays an oncogenic role in extrahepatic cholangiocarcinoma and promotes distance metastasis by EMT [109]. Several studies have reported about ANXA10 in GC. Kim et al. [110] utilized oligonucleotide microarray analysis and array-based comparative genomic hybridization $(\mathrm{CGH})$ to show that the expression of ANXA10 was decreased in several GC cell lines due to DNA loss at the ANXA10 locus in chromosome 4q33. On the other hand, the lack of ANXA10 expression in GC patients was related to disease progression and poor survival [110-112]. A recent study from Japan reported that the loss of ANXA10 expression was detected in $61.2 \%$ of early GC patients and also significantly associated with poor OS [113]. ANXA10 may affect the development of GC by inhibiting the malignant phenotype [114]. When an ANXA10 overexpressing plasmid was introduced into MKN-1 GC cells, the cell growth was suppressed, and apoptosis was augmented [114]. In addition, ANXA10 was also involved in the induction of pancreatic duodenal homeobox 1 (PDX1) expression in GC [112]. The aberrant expression of PDX1 has been reported mainly in the cancers of the digestive organs and served as a tumor suppressor in GC [115]. Taken together, ANXA10 could serve as a tumor suppressor in the progression of GC, while ANXA10 inactivation and absence in GC might be due to chromosomal deletion. Moreover, it might also be used as a novel decision-making biomarker in early GC. Another study showed that the expression profiles of ANXA10 proteins might vary among different tissue types [111]. The expression level of ANXA10 in diffuse-type gastric carcinoma (DGC) was significantly higher than that in intestinal gastric carcinoma (IGC) and had a better 5-year patient survival, whereas IGC with ANXA10 expression had a lower 5-year survival [111]. These results implied that the effect of ANXA10 in the progression of GC might depend on the morphological subtypes. 
ANXA11 in GC. ANXA11 is a member of the annexin A family with the longest $\mathrm{N}$-terminal domain, which contains binding sites that bind to S100 A6 and apoptotic link gene 2 protein (ALG-2) [116]. The dysregulation of ANXA11 expression is closely correlated to the development, prognosis, and chemoresistance of tumors $[69,117,118]$. The high ANXA11 expression of colorectal cancer tissues showed a significant correlation with increasing tumor stage and poor survival [69]. The knockdown of Annexin A11 expression inhibited the proliferation and colony formation ability of ovarian cancer cells while increasing cisplatin resistance to ovarian cancer cells [118]. The low ANXA11 expression may be a potential marker for earlier recurrence of ovarian cancer patients [117]. Notably, ANXA11 could also be used as a target for the lncRNAs-miRNAs-ANXA11 axis to promote the malignant progression of HCC and glioma [119, 120]. Although one study illustrated the oncogenic effect of ANXA11 in GC [121], studies on the potential of ANXA11 in the progression of GC are still scarce. Hua et al. [121] found that ANXA11 was higher in GC tissues than in adjacent mucosa at mRNA and protein levels; it plays significant roles in regulating GC proliferation, migration, and invasion via the AKT/GSK-3 $\beta$ pathway and may be a potential prognostic factor and therapeutic target for GC patients. Nonetheless, a single study is not sufficient for certifying the tumorigenic role in GC, and further investigations are required to explore the specific biological role and molecular mechanism of ANXA11 in GC and other cancers.

\section{Annexin A family in chemotherapy resistance of GC}

Nowadays, surgical resection combined with chemotherapy is the main clinical treatment strategy of GC. However, the characteristics of the rapid proliferation of GC cells and chemotherapy resistance are two major factors leading to the poor prognosis of patients $[122,123]$. Several members of the annexin A family are involved in the chemotherapy resistance of GC. Higher ANXA2 expression was detected in SGC7901/ DDP cells (a drug-resistant GC cell line) compared to parent SGC7901 cells. After the knockdown of ANXA2 expression in SGC7901/DDP cells, the drug sensitivity of doxorubicin, 5-fluorouracil (5-Fu), and cisplatin (DDP) was boosted [124]. ANXA2 may confer chemotherapeutic resistance in GC by regulating MAPK and PI3K/Akt signaling pathways and the expression levels of multiple drug resistance (MDR)-related factors and apoptosis-related proteins [124]. microRNAs have been reported to participate in the regulation of drug resistance in various cancers, including GC [125-128]. miR-101 can alleviate chemoresistance to DDP or vincristine (VCR) of GC cells via inhibiting drug resistance-related gene P-gp by targeting ANXA2 [129]. In addition, ZNF139 may participate in the occurrence, development, and chemosensitivity of GC by promoting the expression of ANXA2 and fascin, while inhibiting the expression of pyridoxal kinase (PDXK) [130]. Japanese scholars [131] proposed a prediction model based on the combination of epidermal growth factor receptor (EGFR) and ANXA3 gene polymorphisms, which could be used to predict the resistance of patients with GC to fluorouracil chemotherapy, providing a theoretical basis for the optimization of chemotherapy regimens for patients before therapy.

ANXA5 is a member of the most abundant and widely distributed annexin A family [132]. The abnormal expression of ANXA5 is associated with drug resistance in various cancers, such as nasopharyngeal carcinoma and glioblastoma $[133,134]$. MPR1 has been considered an energydependent membrane protein transporter that causes tumor resistance by transporting chemotherapeutic agents extracellularly and is highly associated with the poor prognosis of tumor chemotherapy [135]. Wu et al. [136] identified MRP1-interacting proteins in GC through immunoprecipitation-coupled with mass spectrometry, and ANXA5 was the highest scored among a total of 14 interacting proteins. The knockdown of ANXA5 in SGC-7901/DDP significantly increased the sensitivity to chemotherapeutic drugs by decreasing the expression of MRP1 [136]. A Japanese study [137] identified an efficient biomarker for predicting the efficacy of docetaxel, cisplatin, and S-1 (DCS) therapy for advanced GC by microarray assays of biopsy specimens before chemotherapy. The results showed that the expression of ANXA5 was significantly higher in GC tissues of patients without response than in patients with early response, suggesting that ANXA5 may serve as an efficient biomarker for personalized cancer-targeted therapy [137]. In addition to ANXA2 and ANXA5, few studies have been reported the correlation among other members of the annexin A family and chemotherapy resistance in GC. A recent study [138] conducted a comprehensive proteomic analysis of GC-associated fibroblast exosomes (CAF-EV) and found that ANXA6 in CAF-EV activates the focal adhesion kinase (FAK)-YAP. FAK-YAP signaling pathway by the stabilizing $\beta 1$ integrin at the cell surface of GC cells and subsequently induces chemotherapeutics resistance.

Taken together, ANXA2 and ANXA5 are associated with the chemotherapeutic resistance for GC, and the mechanism may be related to the dysexpression of drug-resistant related factors and the abnormal activation of drug-resistant related pathways; these are anticipated to become effective molecular markers to judge the efficacy of GC patients before chemotherapy. Moreover, ANXA6 in CAF-EV plays a crucial role in the network formation and drug resistance of GC cells, providing a novel insight for overcoming GC chemotherapeutic resistance, the role of annexin A family in chemotherapy resistance of GC are outlined in Table 3.

\section{Summary and perspective}

This article summarizes the biological functions and structural characteristics of the annexin A family and reviews the current status of the annexin A family members in GC. The 
putative role of family members in the GC chemotherapeutic resistance is also described in detail. The annexin A family is a polygenic family of $\mathrm{Ca}^{2+}$-regulated phospholipid-binding proteins with functions in $\mathrm{Ca}^{2+}$ signal transduction, cell growth regulation, division, apoptosis, and tumor progression and metastasis. Previous studies have confirmed that several members of the annexin A family are closely linked to the occurrence and development and chemotherapy resistance of GC. Most members of the annexin A family, such as ANXA2, ANXA3, ANXA4, ANXA7, ANXA8, and ANXA11 are highly expressed in GC, which promote the invasion, migration, and metastasis of tumors and influence the prognosis of GC; hence, they can be used as oncogenes in the malignant progression and prognostic markers for GC (Table 1, Table 2). Other family members, including ANXA6 and ANXA10, are lowly expressed in GC, preventing the occurrence and development of GC by inhibiting the proliferation of GC cells (Table 1, Table 2). Moreover, as an anti-inflammatory mediator, ANXA1 is highly expressed in precancerous lesions of gastric mucosa, such as chronic gastritis, which might be involved in the early events of GC. However, in advanced GC, there are discrepancies and contradictions between different studies on the expression level of ANXA1 and prognosis judgment, which might be associated with the tissue origin and specificity of the tumor. Subsequently, ANXA2, ANXA5, and ANXA6 are also involved in the chemotherapeutic resistance of GC via the regulation of drug resistance-related genes and signal transduction pathways (Table3). Therefore, the annexin A family is a prospective novel target for GC therapy and reversal of chemotherapy drug resistance.

In conclusion, annexin A family members might be potential targets for the diagnosis and treatment of GC; however, the underlying mechanisms have not yet been elucidated. With the rapid advancements in science and technology, in-depth investigations are required on annexin A family members in GC and other tumors to provide a theoretical basis and new insights for diagnosing, treating, and preventing the disease.

Acknowledgments: This work was supported by the Natural Science Foundation of Gansu Province (21JR1RA063), the National Natural Science Foundation of China (71964021), and the National Key R\&D Program of China (2016YFC1302201).

\section{References}

[1] YANG J, GONG Y, LAM VK, SHI Y, GUAN Y et al. Deep sequencing of circulating tumor DNA detects molecular residual disease and predicts recurrence in gastric cancer. Cell Death Dis 2020; 11: 346. https://doi.org/10.1038/s41419020-2531-Z

[2] SUNG H, FERLAY J, SIEGEL RL, LAVERSANNE M, SOERJOMATARAM I et al. Global Cancer Statistics 2020: GLOBOCAN Estimates of Incidence and Mortality Worldwide for 36 Cancers in 185 Countries. CA Cancer J Clin 2021; 71: 209-249. https://doi.org/10.3322/caac. 21660
[3] CHEN W, ZHENG R, BAADE PD, ZHANG S, ZENG H et al. Cancer statistics in China, 2015. CA Cancer J Clin 2016; 66: 115-132. https://doi.org/10.3322/caac.21338

[4] CHEN L, ZUO Y, ZHU L, ZHANG Y, LI S et al. Peripheral venous blood neutrophil-to-lymphocyte ratio predicts survival in patients with advanced gastric cancer treated with neoadjuvant chemotherapy. Onco Targets Ther 2017; 10: 2569-2580. https://doi.org/10.2147/OTT.S134716

[5] YANG L, YING X, LIU S, LYU G, XU Z et al. Gastric cancer: Epidemiology, risk factors and prevention strategies. Chin J Cancer Res 2020; 32: 695-704. https://doi.org/10.21147/j. issn.1000-9604.2020.06.03

[6] CATENACCI DVT, KANG Y-K, PARK H, URONIS HE, LEE K-W et al. Margetuximab plus pembrolizumab in patients with previously treated, HER2-positive gastro-oesophageal adenocarcinoma (CP-MGAH22-05): a single-arm, phase 1b-2 trial. The Lancet Oncology 2020; 21: 1066-1076. https://doi.org/10.1016/s1470-2045(20)30326-0

[7] SHITARA K, BANG YJ, IWASA S, SUGIMOTO N, RYU MH et al. Trastuzumab Deruxtecan in Previously Treated HER2Positive Gastric Cancer. N Engl J Med 2020; 382: 2419-2430. https://doi.org/10.1056/NEJMoa2004413

[8] FUKUOKA S, HARA H, TAKAHASHI N, KOJIMA T, KAWAZOE A et al. Regorafenib Plus Nivolumab in Patients With Advanced Gastric or Colorectal Cancer: An OpenLabel, Dose-Escalation, and Dose-Expansion Phase Ib Trial (REGONIVO, EPOC1603). J Clin Oncol 2020; 38: 2053 2061. https://doi.org/10.1200/jco.19.03296

[9] JANJIGIAN YY, MARON SB, CHATILA WK, MILLANG B, CHAVAN SS et al. First-line pembrolizumab and trastuzumab in HER2-positive oesophageal, gastric, or gastrooesophageal junction cancer: an open-label, single-arm, phase 2 trial. Lancet Oncol 2020; 21: 821-831. https://doi. org/10.1016/s1470-2045(20)30169-8

[10] MUSSUNOOR S, MURRAY GI. The role of annexins in tumour development and progression. J Pathol 2008; 216: 131-140. https://doi.org/10.1002/path.2400

[11] LAOHAVISIT A, DAVIES JM. Annexins. New Phytol 2011; 189: 40-53. https://doi.org/10.1111/j.14698137.2010.03533.x

[12] BENAUD C, GENTIL BJ, ASSARD N, COURT M, GARIN $J$ et al. AHNAK interaction with the annexin 2/S100A10 complex regulates cell membrane cytoarchitecture. J Cell Biol 2004; 164: 133-144. https://doi.org/10.1083/ jcb.200307098

[13] LI DH, HE CR, LIU FP, LI J, GAO JW et al. Annexin A2, up-regulated by IL-6, promotes the ossification of ligament fibroblasts from ankylosing spondylitis patients. Biomed Pharmacother 2016; 84: 674-679. https://doi.org/10.1016/j. biopha.2016.09.091

[14] SERET G, CANAS F, POUGNET-DI COSTANZO L, HANROTEL-SALIOU C, JOUSSE-JOULIN S et al. Anti-alpha-actinin antibodies are part of the anti-cell membrane antibody spectrum that characterize patients with lupus nephritis. J Autoimmun 2015; 61: 54-61. https://doi.org/10.1016/j. jaut.2015.05.009 
[15] DIAZ VM, HURTADO M, THOMSON TM, REVENTOS J, PACIUCCI R. Specific interaction of tissue-type plasminogen activator ( $t-P A)$ with annexin II on the membrane of pancreatic cancer cells activates plasminogen and promotes invasion in vitro. Gut 2004; 53: 993-1000. https://doi. org/10.1136/gut.2003.026831

[16] SHARMA MC. Annexin A2 (ANX A2): An emerging biomarker and potential therapeutic target for aggressive cancers. Int J Cancer 2019; 144: 2074-2081. https://doi. org/10.1002/ijc.31817

[17] XUE G, HAO LQ, DING FX, MEI Q, HUANG JJ et al. Expression of annexin a5 is associated with higher tumor stage and poor prognosis in colorectal adenocarcinomas. J Clin Gastroenterol 2009; 43: 831-837. https://doi.org/10.1097/ MCG.0b013e31819cc731

[18] TOROSYAN Y, DOBI A, GLASMAN M, MEZHEVAYA K, NAGA $S$ et al. Role of multi-hnRNP nuclear complex in regulation of tumor suppressor ANXA7 in prostate cancer cells. Oncogene 2010; 29: 2457-2466. https://doi.org/10.1038/ onc. 2010.2

[19] XU XH, PAN W, KANG LH, FENG H, SONG YQ. Association of annexin A2 with cancer development (Review). Oncol Rep 2015; 33: 2121-2128. https://doi.org/10.3892/ or.2015.3837

[20] GERKE V, MOSS SE. Annexins: from structure to function. Physiol Rev 2002; 82: 331-371. https://doi.org/10.1152/ physrev.00030.2001

[21] RESCHER U, GERKE V. Annexins--unique membrane binding proteins with diverse functions. J Cell Sci 2004; 117: 2631-2639. https://doi.org/10.1242/jcs.01245

[22] GERKE V, CREUTZ CE, MOSS SE. Annexins: linking Ca2+ signalling to membrane dynamics. Nat Rev Mol Cell Biol 2005; 6: 449-461. https://doi.org/10.1038/nrm1661

[23] MORTIMER JC, LAOHAVISIT A, MACPHERSON N, WEBB A, BROWNLEE $C$ et al. Annexins: multifunctional components of growth and adaptation. J Exp Bot 2008; 59: 533-544. https://doi.org/10.1093/jxb/erm344

[24] ZHOU T, LI Y, YANG L, LIU L, JU Y et al. Silencing of ANXA3 expression by RNA interference inhibits the proliferation and invasion of breast cancer cells. Oncol Rep 2017; 37: 388-398. https://doi.org/10.3892/or.2016.5251

[25] HANAHAN D, WEINBERG RA. Hallmarks of cancer: the next generation. Cell 2011; 144: 646-674. https://doi. org/10.1016/j.cell.2011.02.013

[26] XIE YQ, FU D, HE ZH, TAN QD. Prognostic value of Annexin A3 in human colorectal cancer and its correlation with hypoxia-inducible factor-1alpha. Oncol Lett 2013; 6: 16311635. https://doi.org/10.3892/ol.2013.1620

[27] XU R, YIN J, ZHANG Y, ZHANG S. Annexin A3 depletion overcomes resistance to oxaliplatin in colorectal cancer via the MAPK signaling pathway. J Cell Biochem 2019; 120: 14585-14593. https://doi.org/10.1002/jcb.28720

[28] YU S, BIAN H, GAO X, GUI L. Annexin A9 promotes invasion and metastasis of colorectal cancer and predicts poor prognosis. Int J Mol Med 2018; 41: 2185-2192. https://doi. org/10.3892/ijmm.2018.3432
[29] BAI F, ZHANG P, FU Y, CHEN H, ZHANG M et al. Targeting ANXA1 abrogates Treg-mediated immune suppression in triple-negative breast cancer. J Immunother Cancer 2020; 8: https://doi.org/10.1136/jitc-2019-000169

[30] MORAES LA, KAR S, FOO SL, GU T, TOH YQ et al. Annexin-A1 enhances breast cancer growth and migration by promoting alternative macrophage polarization in the tumour microenvironment. Sci Rep 2017; 7: 17925. https://doi. org/10.1038/s41598-017-17622-5

[31] TEBAR F, GELABERT-BALDRICH M, HOQUE M, CAIRNS R, RENTERO C et al. Annexins and endosomal signaling. Methods Enzymol 2014; 535: 55-74. https://doi. org/10.1016/B978-0-12-397925-4.00004-3

[32] PERRETTI M, D’ACQUISTO F. Annexin A1 and glucocorticoids as effectors of the resolution of inflammation. Nature reviews. Immunology 2009; 9: 62-70. https://doi. org $/ 10.1038 /$ nri2470

[33] DELORME S, PRIVAT M, SONNIER N, ROUANET J, WITKOWSKI $\mathrm{T}$ et al. New insight into the role of ANXA1 in melanoma progression: involvement of stromal expression in dissemination. Am J Cancer Res 2021; 11: 1600-1615.

[34] OSHI M, TOKUMARU Y, MUKHOPADHYAY S, YAN L, MATSUYAMA R et al. Annexin A1 Expression Is Associated with Epithelial-Mesenchymal Transition (EMT), Cell Proliferation, Prognosis, and Drug Response in Pancreatic Cancer. Cells 2021; 10: https://doi.org/10.3390/cells10030653

[35] OKANO M, OSHI M, BUTASH AL, KATSUTA E, TACHIBANA $\mathrm{K}$ et al. Triple-Negative Breast Cancer with High Levels of Annexin A1 Expression Is Associated with Mast Cell Infiltration, Inflammation, and Angiogenesis. Int J Mol Sci 2019; 20: https://doi.org/10.3390/ijms20174197

[36] ZHU JF, HUANG W, YI HM, XIAO T, LI JY et al. Annexin A1-suppressed autophagy promotes nasopharyngeal carcinoma cell invasion and metastasis by PI3K/AKT signaling activation. Cell Death Dis 2018; 9: 1154. https://doi. org/10.1038/s41419-018-1204-7

[37] MARTIN GR, PERRETTI M, FLOWER RJ, WALLACE JL. Annexin-1 modulates repair of gastric mucosal injury. Am J Physiol Gastrointest Liver Physiol 2008; 294: G764-769. https://doi.org/10.1152/ajpgi.00531.2007

[38] ROSSI AF, DUARTE MC, POLTRONIERI AB, VALSECHI MC, JORGE YC et al. Deregulation of annexin-A1 and galectin-1 expression in precancerous gastric lesions: intestinal metaplasia and gastric ulcer. Mediators Inflamm 2014; 2014: 478138. https://doi.org/10.1155/2014/478138

[39] TAKAOKA RTC, SERTORIO ND, MAGALINI LPJ, DOS SANTOS LM, SOUZA HR et al. Expression profiles of Annexin A1, formylated peptide receptors and cyclooxigenase-2 in gastroesophageal inflammations and neoplasias. Pathol Res Pract 2018; 214: 181-186. https://doi.org/10.1016/j. prp.2017.12.003

[40] JORGE YC, MATARUCO MM, ARAUJO LP, ROSSI AF, DE OLIVEIRA JG et al. Expression of annexin-A1 and galectin-1 anti-inflammatory proteins and mRNA in chronic gastritis and gastric cancer. Mediators Inflamm 2013; 2013: 152860. https://doi.org/10.1155/2013/152860 
[41] ZHANG ZQ, LI XJ, LIU GT, XIA Y, ZHANG XY et al. Identification of Annexin A1 protein expression in human gastric adenocarcinoma using proteomics and tissue microarray. World J Gastroenterol 2013; 19: 7795-7803. https://doi. org/10.3748/wjg.v19.i43.7795

[42] WANG X, ZHI Q, LIU S, XUE SL, SHEN C et al. Identification of specific biomarkers for gastric adenocarcinoma by ITRAQ proteomic approach. Sci Rep 2016; 6: 38871. https:// doi.org/10.1038/srep38871

[43] CHENG TY, WU MS, LIN JT, LIN MT, SHUN CT et al. Annexin A1 is associated with gastric cancer survival and promotes gastric cancer cell invasiveness through the formyl peptide receptor/extracellular signal-regulated kinase/integrin beta-1-binding protein 1 pathway. Cancer 2012; 118: 5757-5767. https://doi.org/10.1002/cncr.27565

[44] SATO Y, KUMAMOTO K, SAITO K, OKAYAMA H, HAYASE $S$ et al. Up-regulated Annexin A1 expression in gastrointestinal cancer is associated with cancer invasion and lymph node metastasis. Exp Ther Med 2011; 2: 239-243. https://doi.org/10.3892/etm.2011.210

[45] YU G, WANG J, CHEN Y, WANG X, PAN J et al. Tissue microarray analysis reveals strong clinical evidence for a close association between loss of annexin A1 expression and nodal metastasis in gastric cancer. Clin Exp Metastasis 2008; 25: 695-702. https://doi.org/10.1007/s10585-008-9178-y

[46] GAO Y, CHEN Y, XU D, WANG J, YU G. Differential expression of ANXA1 in benign human gastrointestinal tissues and cancers. BMC Cancer 2014; 14: 520. https://doi. org/10.1186/1471-2407-14-520

[47] ZHU F, XU C, JIANG Z, JIN M, WANG L et al. Nuclear localization of annexin A1 correlates with advanced disease and peritoneal dissemination in patients with gastric carcinoma. Anat Rec (Hoboken) 2010; 293: 1310-1314. https:// doi.org/10.1002/ar.21176

[48] FENG J, XIAO T, LU SS, HUNG XP, YI H et al. ANXA1derived peptides suppress gastric and colon cancer cell growth by targeting EphA2 degradation. Int J Oncol 2020; 57: 1203-1213. https://doi.org/10.3892/ijo.2020.5119

[49] CANCER GENOME ATLAS RESEARCH N. Comprehensive molecular characterization of gastric adenocarcinoma. Nature 2014; 513: 202-209. https://doi.org/10.1038/nature 13480

[50] HAJJAR KA, KRISHNAN S. Annexin II: a mediator of the plasmin/plasminogen activator system. Trends Cardiovasc Med 1999; 9: 128-138. https://doi.org/10.1016/s10501738(99)00020-1

[51] TAN HL, TAN BZ, GOH WXT, CUA S, CHOO A. In vivo surveillance and elimination of teratoma-forming human embryonic stem cells with monoclonal antibody 2448 targeting annexin A2. Biotechnol Bioeng 2019; 116: 2996-3005. https://doi.org/10.1002/bit.27135

[52] YAN X, ZHANG D, WU W, WU S, QIAN J et al. Mesenchymal Stem Cells Promote Hepatocarcinogenesis via lncRNAMUF Interaction with ANXA2 and miR-34a. Cancer Res 2017; 77: 6704-6716. https://doi.org/10.1158/0008-5472. CAN-17-1915
[53] MOREL E, GRUENBERG J. Annexin A2 binding to endosomes and functions in endosomal transport are regulated by tyrosine 23 phosphorylation. J Biol Chem 2009; 284: 1604-1611. https://doi.org/10.1074/jbc.M806499200

[54] WANG CY, LIN CF. Annexin A2: its molecular regulation and cellular expression in cancer development. Dis Markers 2014; 2014: 308976. https://doi.org/10.1155/2014/308976

[55] SHETTY PK, THAMAKE SI, BISWAS S, JOHANSSON SL, VISHWANATHA JK. Reciprocal regulation of annexin A2 and EGFR with Her-2 in Her-2 negative and herceptin-resistant breast cancer. PLoS One 2012; 7: e44299. https://doi. org/10.1371/journal.pone.0044299

[56] ALONSO-ALCONADA L, SANTACANA M, GARCIASANZ P, MUINELO-ROMAY L, COLAS E et al. AnnexinA2 as predictor biomarker of recurrent disease in endometrial cancer. Int J Cancer 2015; 136: 1863-1873. https://doi. org/10.1002/ijc.29213

[57] GIBBS LD, VISHWANATHA JK. Prognostic impact of AnxA1 and AnxA2 gene expression in triple-negative breast cancer. Oncotarget 2018; 9: 2697-2704. https://doi. org/10.18632/oncotarget.23627

[58] XIE R, LIU J, YU X, LI C, WANG Y et al. ANXA2 Silencing Inhibits Proliferation, Invasion, and Migration in Gastric Cancer Cells. J Oncol 2019; 2019: 4035460. https://doi. org/10.1155/2019/4035460

[59] HAN F, SHRESTHA S, HUANG H, LV HY, NIE C et al. Expression of annexin II in gastric carcinoma and its role in gastric cancer metastasis. World J Gastroenterol 2017; 23: 7009-7015. https://doi.org/10.3748/wjg.v23.i38.7009

[60] ZHANG Q, YE Z, YANG Q, HE X, WANG H et al. Upregulated expression of annexin II is a prognostic marker for patients with gastric cancer. World J Surg Oncol 2012; 10: 103. https://doi.org/10.1186/1477-7819-10-103

[61] GIRARD C, TINEL N, TERRENOIRE C, ROMEY G, LAZDUNSKI $M$ et al. p11, an annexin II subunit, an auxiliary protein associated with the background $\mathrm{K}+$ channel, TASK1. EMBO J 2002; 21: 4439-4448. https://doi.org/10.1093/emboj/cdf469

[62] LI Y, LI XY, LI LX, ZHOU RC, SIKONG Y et al. S100A10 Accelerates Aerobic Glycolysis and Malignant Growth by Activating mTOR-Signaling Pathway in Gastric Cancer. Front Cell Dev Biol 2020; 8: 559486. https://doi.org/10.3389/ fcell.2020.559486

[63] PERRON B, LEWIT-BENTLEY A, GENY B, RUSSO-MARIE F. Can enzymatic activity, or otherwise, be inferred from structural studies of annexin III? J Biol Chem 1997; 272: 11321-11326. https://doi.org/10.1074/jbc.272.17.11321

[64] TAIT JF, FRANKENBERRY DA, MIAO CH, KILLARY AM, ADLER DA et al. Chromosomal localization of the human annexin III (ANX3) gene. Genomics 1991; 10: 441-448. https://doi.org/10.1016/0888-7543(91)90330-h

[65] JUNG EJ, MOON HG, PARK ST, CHO BI, LEE SM et al. Decreased annexin A3 expression correlates with tumor progression in papillary thyroid cancer. Proteomics Clin Appl 2010; 4: 528-537. https://doi.org/10.1002/prca.200900063 
[66] KOLLERMANN J, SCHLOMM T, BANG H, SCHWALL GP, VON EICHEL-STREIBER C et al. Expression and prognostic relevance of annexin A3 in prostate cancer. Eur Urol 2008; 54: 1314-1323. https://doi.org/10.1016/j.eururo.2008.01.001

[67] YU SY, LI Y, FAN LQ, ZHAO Q, TAN BB et al. Impact of Annexin A3 expression in gastric cancer cells. Neoplasma 2014; 61: 257-264. https://doi.org/10.4149/neo_2014_033

[68] WANG J, JIA X, MENG X, LI Y, WU W et al. Annexin A3 may play an important role in ochratoxin-induced malignant transformation of human gastric epithelium cells. Toxicol Lett 2019; 313: 150-158. https://doi.org/10.1016/j. toxlet.2019.07.002

[69] DUNCAN R, CARPENTER B, MAIN LC, TELFER C, MURRAY GI. Characterisation and protein expression profiling of annexins in colorectal cancer. Br J Cancer 2008; 98: 426-433. https://doi.org/10.1038/sj.bjc.6604128

[70] MIAO Y, CAI B, LIU L, YANG Y, WAN X. Annexin IV is differentially expressed in clear cell carcinoma of the ovary. Int J Gynecol Cancer 2009; 19: 1545-1549. https://doi. org/10.1111/IGC.0b013e3181a844c8

[71] TOYAMA A, SUZUKI A, SHIMADA T, AOKI C, AOKI Y et al. Proteomic characterization of ovarian cancers identifying annexin-A4, phosphoserine aminotransferase, cellular retinoic acid-binding protein 2, and serpin B5 as histologyspecific biomarkers. Cancer Sci 2012; 103: 747-755. https:// doi.org/10.1111/j.1349-7006.2012.02224.x

[72] ZIMMERMANN U, BALABANOV S, GIEBEL J, TELLER S, JUNKER $\mathrm{H}$ et al. Increased expression and altered location of annexin IV in renal clear cell carcinoma: a possible role in tumour dissemination. Cancer Lett 2004; 209: 111-118. https://doi.org/10.1016/j.canlet.2003.12.002

[73] XIN W, RHODES DR, INGOLD C, CHINNAIYAN AM, RUBIN MA. Dysregulation of the Annexin Family Protein Family Is Associated with Prostate Cancer Progression. Am J Pathol 2003; 162: 255-261. https://doi.org/10.1016/s00029440(10)63816-3

[74] LIU J, WANG H, ZHENG M, DENG L, ZHANG X et al. p53 and ANXA4/NF- $\kappa$ B p50 complexes regulate cell proliferation, apoptosis and tumor progression in ovarian clear cell carcinoma. Int J Mol Med 2020; 46: 2102-2114. https://doi. org/10.3892/ijmm.2020.4757

[75] LI L, ZHANG R, LIU Y, ZHANG G. ANXA4 Activates JAKSTAT3 Signaling by Interacting with ANXA1 in Basal-Like Breast Cancer. DNA Cell Biol 2020; 39: 1649-1656. https:// doi.org/10.1089/dna.2020.5570

[76] LIU YY, GE C, TIAN H, JIANG JY, ZHAO FY et al. The transcription factor Ikaros inhibits cell proliferation by downregulating ANXA4 expression in hepatocellular carcinoma. Am J Cancer Res 2017; 7: 1285-1297.

[77] YAO HS, SUN C, LI XX, WANG Y, JIN KZ et al. Annexin A4-nuclear factor-kappaB feedback circuit regulates cell malignant behavior and tumor growth in gallbladder cancer. Sci Rep 2016; 6: 31056. https://doi.org/10.1038/srep31056

[78] MATSUZAKI S, SERADA S, MORIMOTO A, UEDA Y, YOSHINO K et al. Annexin A4 is a promising therapeutic target for the treatment of platinum-resistant cancers. Expert Opin Ther Targets 2014; 18: 403-414. https://doi.org/10.1517/147 28222.2014 .882323
[79] LIN LL, CHEN CN, LIN WC, LEE PH, CHANG KJ et al. Annexin A4: A novel molecular marker for gastric cancer with Helicobacter pylori infection using proteomics approach. Proteomics Clin Appl 2008; 2: 619-634. https://doi. org/10.1002/prca.200780088

[80] LIN LL, HUANG HC, OGIHARA S, WANG JT, WU MC et al. Helicobacter pylori disrupts host cell membranes, initiating a repair response and cell proliferation. Int J Mol Sci 2012; 13: 10176-10192. https://doi.org/10.3390/ijms130810176

[81] LIN LL, HUANG HC, JUAN HF. Revealing the molecular mechanism of gastric cancer marker annexin A4 in cancer cell proliferation using exon arrays. PLoS One 2012; 7: e44615. https://doi.org/10.1371/journal.pone.0044615

[82] LI J, ZHANG B, CUI J, LIANG Z, LIU K. miR-203 Inhibits the Invasion and EMT of Gastric Cancer Cells by Directly Targeting Annexin A4. Oncol Res 2019; 27: 789-799. https:// doi.org/10.3727/096504018X15444387696532

[83] SMITH PD, DAVIES A, CRUMPTON MJ, MOSS SE. Structure of the human annexin VI gene. Proc Natl Acad Sci U S A 1994; 91: 2713-2717. https://doi.org/10.1073/pnas.91.7.2713

[84] GREWAL T, KOESE M, RENTERO C, ENRICH C. Annexin A6-regulator of the EGFR/Ras signalling pathway and cholesterol homeostasis. Int J Biochem Cell Biol 2010; 42: 580584. https://doi.org/10.1016/j.biocel.2009.12.020

[85] FRANCIA G, MITCHELL SD, MOSS SE, HANBY AM, MARSHALL JF et al. Identification by differential display of annexin-VI, a gene differentially expressed during melanoma progression. Cancer Res 1996; 56: 3855-3858.

[86] THEOBALD J, HANBY A, PATEL K, MOSS SE. Annexin VI has tumour-suppressor activity in human A431 squamous epithelial carcinoma cells. Br J Cancer 1995; 71: 786-788. https://doi.org/10.1038/bjc.1995.152

[87] QI H, LIU S, GUO C, WANG J, GREENAWAY FT et al. Role of annexin A6 in cancer. Oncol Lett 2015; 10: 1947-1952. https://doi.org/10.3892/ol.2015.3498

[88] WANG X, ZHANG S, ZHANG J, LAM E, LIU X et al. Annexin A6 is down-regulated through promoter methylation in gastric cancer. Am J Transl Res 2013; 5: 555-562.

[89] MATSUKAWA Y, SEMBA S, KATO H, ITO A, YANAGIHARA K et al. Expression of the enhancer of zeste homolog 2 is correlated with poor prognosis in human gastric cancer. Cancer Sci 2006; 97: 484-491. https://doi.org/10.1111/ j.1349-7006.2006.00203.X

[90] QI Y, ZHANG X, KANG Y, WU J, CHEN J et al. Genomewide transcriptional profiling analysis reveals annexin A6 as a novel EZH2 target gene involving gastric cellular proliferation. Mol Biosyst 2015; 11: 1980-1986. https://doi. org/10.1039/c5mb00233h

[91] HUANG H, ZHANG J, LING F, HUANG Y, YANG $\mathrm{M}$ et al. Leptin Receptor (LEPR) promotes proliferation, migration, and invasion and inhibits apoptosis in hepatocellular carcinoma by regulating ANXA7. Cancer Cell Int 2021; 21: 4. https://doi.org/10.1186/s12935-020-01641-w

[92] LIU H, GUO D, SHA Y, ZHANG C, JIANG Y et al. ANXA7 promotes the cell cycle, proliferation and cell adhesion-mediated drug resistance of multiple myeloma cells by up-regulating CDC5L. Aging 2020; 12: 11100-11115. https://doi. org/10.18632/aging.103326 
[93] PAN SJ, ZHAN SK, JI WZ, PAN YX, LIU W et al. Ubiquitinprotein ligase $\mathrm{E} 3 \mathrm{C}$ promotes glioma progression by mediating the ubiquitination and degrading of Annexin A7. Sci Rep 2015; 5: 11066. https://doi.org/10.1038/srep11066

[94] TOROSYAN Y, SIMAKOVA O, NAGA S, MEZHEVAYA $\mathrm{K}$, LEIGHTON X et al. Annexin-A7 protects normal prostate cells and induces distinct patterns of RB-associated cytotoxicity in androgen-sensitive and -resistant prostate cancer cells. Int J Cancer 2009; 125: 2528-2539. https://doi. org/10.1002/ijc.24592

[95] HUANG Y, WANG H, YANG Y. Annexin A7 is correlated with better clinical outcomes of patients with breast cancer. J Cell Biochem 2018; 119: 7577-7584. https://doi.org/10.1002/ jcb. 27087

[96] HSU PI, HUANG MS, CHEN HC, HSU PN, LAI TC et al. The significance of ANXA7 expression and its correlation with poor cellular differentiation and enhanced metastatic potential of gastric cancer. J Surg Oncol 2008; 97: 609-614. https://doi.org/10.1002/jso.21046

[97] YUAN HF, LI Y, ZHAO Q, FAN LQ, TAN BB et al. Expression of annexin A7 and its clinical significance in differentiation and metastasis of gastric carcinoma. Int J Clin Exp Pathol 2014; 7: 6567-6574.

[98] SUN MZ, LIU S, TANG J, WANG Z, GONG X et al. Proteomics analysis of two mice hepatocarcinoma ascites syngeneic cell lines with high and low lymph node metastasis rates provide potential protein markers for tumor malignancy attributes to lymphatic metastasis. Proteomics 2009; 9: 32853302. https://doi.org/10.1002/pmic.200701002

[99] YUAN HF, LI Y, YE WH, LIU Y, ZHANG ZD et al. Downregulation of annexin A7 decreases proliferation, migration, and invasion of gastric cancer cells by reducing matrix metalloproteinase 1 and 9 expression. Am J Transl Res 2019; 11: 2754-2764.

[100] YE W, LI Y, FAN L, ZHAO Q, YUAN H et al. Effect of annexin A7 suppression on the apoptosis of gastric cancer cells. Mol Cell Biochem 2017; 429: 33-43. https://doi.org/10.1007/ s11010-016-2934-4

[101] GOEBELER V, POETER M, ZEUSCHNER D, GERKE V, RESCHER U. Annexin A8 regulates late endosome organization and function. Mol Biol Cell 2008; 19: 5267-5278. https://doi.org/10.1091/mbc.E08-04-0383

[102] GREWAL T, ENRICH C. Annexins--modulators of EGF receptor signalling and trafficking. Cell Signal 2009; 21: 847858. https://doi.org/10.1016/j.cellsig.2009.01.031

[103] POETER M, BRANDHERM I, ROSSAINT J, ROSSO G, SHAHIN V et al. Annexin A8 controls leukocyte recruitment to activated endothelial cells via cell surface delivery of CD63. Nat Commun 2014; 5: 3738. https://doi.org/10.1038/ ncomms 4738

[104] MA F, LI X, FANG H, JIN Y, SUN Q et al. Prognostic Value of ANXA8 in Gastric Carcinoma. J Cancer 2020; 11: 35513558. https://doi.org/10.7150/jca. 40010

[105] WEI T, ZHU X. Knockdown of ANXA10 inhibits proliferation and promotes apoptosis of papillary thyroid carcinoma cells by down-regulating TSG101 thereby inactivating the MAPK/ERK signaling pathway. J Bioenerg Biomembr 2021; https://doi.org/10.1007/s10863-021-09902-7
[106] KIM JH, RHEE YY, KIM KJ, CHO NY, LEE HS et al. Annexin A10 expression correlates with serrated pathway features in colorectal carcinoma with microsatellite instability. APMIS 2014; 122: 1187-1195. https://doi.org/10.1111/apm.12284

[107] PENG SY, OU YH, CHEN WJ, LI HY, LIU SH et al. Aberrant expressions of annexin A10 short isoform, osteopontin and alpha-fetoprotein at chromosome $4 \mathrm{q}$ cooperatively contribute to progression and poor prognosis of hepatocellular carcinoma. Int J Oncol 2005; 26: 1053-1061.

[108] LIU S-H, LIN C-Y, PENG S-Y, JENG Y-M, PAN H-W et al. Down-Regulation of Annexin A10 in Hepatocellular Carcinoma Is Associated with Vascular Invasion, Early Recurrence, and Poor Prognosis in Synergy with p53 Mutation. Am J Pathol 2002; 160: 1831-1837. https://doi.org/10.1016/ s0002-9440(10)61129-7

[109] SUN R, LIU Z, QIU B, CHEN T, LI Z et al. Annexin10 promotes extrahepatic cholangiocarcinoma metastasis by facilitating EMT via PLA2G4A/PGE2/STAT3 pathway. EBioMedicine 2019; 47: 142-155. https://doi.org/10.1016/j. ebiom.2019.08.062

[110] KIM J, KIM MA, JEE CD, JUNG EJ, KIM WH. Reduced expression and homozygous deletion of annexin A10 in gastric carcinoma. Int J Cancer 2009; 125: 1842-1850. https://doi. org/10.1002/ijc.24541

[111] LU SH, CHEN YL, SHUN CT, LAI JN, PENG SY et al. Expression and prognostic significance of gastric-specific annexin A10 in diffuse- and intestinal-type gastric carcinoma. J Gastroenterol Hepatol 2011; 26: 90-97. https://doi. org/10.1111/j.1440-1746.2010.06480.x

[112] ISHIKAWA A, SAKAMOTO N, HONMA R, TANIYAMA $\mathrm{D}, \mathrm{FUKADA} \mathrm{K}$ et al. Annexin A10 is involved in the induction of pancreatic duodenal homeobox 1 in gastric cancer tissue, cells and organoids. Oncol Rep 2020; 43: 581-590. https://doi.org/10.3892/or.2019.7422

[113] ISHIKAWA A, KURAOKA K, ZAITSU J, SAITO A, KUWAIT et al. Loss of Annexin A10 Expression Is Associated with Poor Prognosis in Early Gastric Cancer. Acta Histochem Cytochem 2020; 53: 113-119. https://doi.org/10.1267/ahc.20-00014

[114] NAM. Decreased expression of Annexin A10 in gastric cancer and its overexpression in tumor cell growth suppression. Oncol Rep 2010; 24: https://doi.org/10.3892/or_00000898

[115] MA J, CHEN M, WANG J, XIA HH, ZHU S et al. Pancreatic duodenal homeobox-1 (PDX1) functions as a tumor suppressor in gastric cancer. Carcinogenesis 2008; 29: 1327 1333. https://doi.org/10.1093/carcin/bgn112

[116] WILLIAMS LH, MCCLIVE PJ, VAN DEN BERGEN JA, SINCLAIR AH. Annexin XI co-localises with calcyclin in proliferating cells of the embryonic mouse testis. Dev Dyn 2005; 234: 432-437. https://doi.org/10.1002/dvdy.20548

[117] SONG J, SHIH IE M, SALANI R, CHAN DW, ZHANG Z. Annexin XI is associated with cisplatin resistance and related to tumor recurrence in ovarian cancer patients. Clin Cancer Res 2007; 13: 6842-6849. https://doi.org/10.1158/1078-0432. CCR-07-0569

[118] SONG J, SHIH IE M, CHAN DW, ZHANG Z. Suppression of annexin A11 in ovarian cancer: implications in chemoresistance. Neoplasia 2009; 11: 605-614, 601 p following 614. https://doi.org/10.1593/neo.09286 
[119] LIU Z, WANG Y, WANG L, YAO B, SUN L et al. Long noncoding RNA AGAP2-AS1, functioning as a competitive endogenous RNA, upregulates ANXA11 expression by sponging $\mathrm{miR}-16-5 \mathrm{p}$ and promotes proliferation and metastasis in hepatocellular carcinoma. J Exp Clin Cancer Res 2019; 38 : 194. https://doi.org/10.1186/s13046-019-1188-x

[120] QI J, WANG Z, ZHAO Z, LIU L. EIF3J-AS1 promotes glioma cell growth via up-regulating ANXA11 through sponging miR-1343-3p. Cancer Cell Int 2020; 20: 428. https://doi. org/10.1186/s12935-020-01487-2

[121] HUA K, LI Y, ZHAO Q, FAN L, TAN B et al. Downregulation of Annexin A11 (ANXA11) Inhibits Cell Proliferation, Invasion, and Migration via the AKT/GSK-3beta Pathway in Gastric Cancer. Med Sci Monit 2018; 24: 149-160. https:// doi.org/10.12659/msm.905372

[122] MACHADO RA, DE FREITAS EM, DE AQUINO SN, MARTELLI DR, SWERTS MS et al. Clinical relevance of breast and gastric cancer-associated polymorphisms as potential susceptibility markers for oral clefts in the Brazilian population. BMC Med Genet 2017; 18: 39. https://doi.org/10.1186/ s12881-017-0390-y

[123] MARIN JJ, AL-ABDULLA R, LOZANO E, BRIZ O, BUJANDA L et al. Mechanisms of Resistance to Chemotherapy in Gastric Cancer. Anticancer Agents Med Chem 2016; 16: 318-334. https://doi.org/10.2174/1871520615666150803125 121

[124] ZHANG ZD, LI Y, FAN Q, ZHAO B, TAN B et al. Annexin A2 is implicated in multi-drug-resistance in gastric cancer through p38MAPK and AKT pathway. Neoplasma 2014; 61: 627-637. https://doi.org/10.4149/neo_2014_078

[125] XIA W, LIU Y, DU Y, CHENG T, HU X et al. MicroRNA-423 Drug Resistance and Proliferation of Breast Cancer Cells by Targeting ZFP36. Onco Targets Ther 2020; 13: 769-782. https://doi.org/10.2147/OTT.S217745

[126] ZHAN T, HUANG X, TIAN X, CHEN X, DING Y et al. Downregulation of MicroRNA-455-3p Links to Proliferation and Drug Resistance of Pancreatic Cancer Cells via Targeting TAZ. Mol Ther Nucleic Acids 2018; 10: 215-226. https://doi. org/10.1016/j.omtn.2017.12.002

[127] JI R, ZHANG X, GU H, MA J, WEN X et al. miR-374a-5p: A New Target for Diagnosis and Drug Resistance Therapy in Gastric Cancer. Mol Ther Nucleic Acids 2019; 18: 320-331. https://doi.org/10.1016/j.omtn.2019.07.025

[128] HUANG H, TANG J, ZHANG L, BU Y, ZHANG X. miR-874 regulates multiple-drug resistance in gastric cancer by targeting ATG16L1. Int J Oncol 2018; 53: 2769-2779. https:// doi.org/10.3892/ijo.2018.4593
[129] BAO J, XU Y, WANG Q, ZHANG J, LI Z et al. miR-101 alleviates chemoresistance of gastric cancer cells by targeting ANXA2. Biomed Pharmacother 2017; 92: 1030-1037. https://doi.org/10.1016/j.biopha.2017.06.011

[130] HAO YJ, LI Y, FAN LQ, ZHAO Q, TAN BB et al. Role of RNA-interference-induced zinc finger protein 139 suppression in gastric cancer cell sensitivity to chemotherapeutic agents. Oncol Lett 2015; 10: 1333-1338. https://doi. org/10.3892/ol.2015.3421

[131] TAKAHASHI H, KANIWA N, SAITO Y, SAI K, HAMAGU$\mathrm{CHI} \mathrm{T}$ et al. Construction of possible integrated predictive index based on EGFR and ANXA3 polymorphisms for chemotherapy response in fluoropyrimidine-treated Japanese gastric cancer patients using a bioinformatic method. BMC Cancer 2015; 15: 718. https://doi.org/10.1186/s12885-015$1721-\mathrm{z}$

[132] SOPKOVA-DE OLIVEIRA SANTOS J, VINCENT M, TABARIES S, CHEVALIER A, KERBOEUF D et al. Annexin A5 D226K structure and dynamics: identification of a molecular switch for the large-scale conformational change of domain III. FEBS Lett 2001; 493: 122-128. https://doi. org/10.1016/s0014-5793(01)02285-2

[133] TANG S, HUANG W, ZHONG M, YIN L, JIANG $\mathrm{H}$ et al. Identification Keratin 1 as a cDDP-resistant protein in nasopharyngeal carcinoma cell lines. J Proteomics 2012; 75: 2352-2360. https://doi.org/10.1016/j.jprot.2012.02.003

[134] WU L, YANG L, XIONG Y, GUO H, SHEN X et al. Annexin A5 promotes invasion and chemoresistance to temozolomide in glioblastoma multiforme cells. Tumour Biol 2014; 35: 12327-12337. https://doi.org/10.1007/s13277-014-2545-1

[135] ARANA MR, ALTENBERG GA. ATP-binding Cassette Exporters: Structure and Mechanism with a Focus on P-glycoprotein and MRP1. Curr Med Chem 2019; 26: 1062-1078. https://doi.org/10.2174/0929867324666171012105143

[136] WU X, TANG Y, HUANG W, WU Y. Identification of proteins interacting with multidrug resistance protein in gastric cancer. World Chin J Dig 2011; 19: 3568-3573. https://doi. org/CNKI:SUN:XXHB.0.2011-35-004

[137] KITAMURA S, TANAHASHI T, AOYAGI E, NAKAGAWA T, OKAMOTO K et al. Response Predictors of S-1, Cisplatin, and Docetaxel Combination Chemotherapy for Metastatic Gastric Cancer: Microarray Analysis of Whole Human Genes. Oncology 2017; 93: 127-135. https://doi. org/10.1159/000464329

[138] UCHIHARA T, MIYAKE K, YONEMURA A, KOMOHARA Y, ITOYAMA R et al. Extracellular Vesicles from Cancer-Associated Fibroblasts Containing Annexin A6 Induces FAKYAP Activation by Stabilizing betal Integrin, Enhancing Drug Resistance. Cancer Res 2020; 80: 3222-3235. https:// doi.org/10.1158/0008-5472.CAN-19-3803 